ISSN 1678-3921

Journal homepage: www.embrapa.br/pab

For manuscript submission and journal contents, access: www.scielo.br/pab
Valquíria Sousa Silva ${ }^{(1 凶)}(\mathrm{D}$, Kênia Ferreira Rodrigues ${ }^{(2)}$ (iD), Everton Luis Krabbe ${ }^{(3)}$ (iD), Roberta Gomes Marçal Vieira Vaz ${ }^{(2)}$ (D), Valdir Silveira de Ávila(3) (D) and Cristiele Lange Contreira ${ }^{(4)}$ (iD

(1) Universidade Federal do Ceará, Centro de Ciências Agrárias, Departamento de Zootecnia, Campus do Pici, Bloco 810, CEP 60440-900 Fortaleza, CE, Brazil. E-mail: Walzoouft@gmail.com

(2) Universidade Federal do Tocantins, Escola de Medicina Veterinária e Zootecnia, Departamento de Zootecnia, Campus de Araguaína, BR-153, Km 112, s/no , Caixa Postal 132, CEP 77804-970 Araguaína, TO, Brazil.

E-mail: rodrigueskf@mail.uft.edu.br, betagmvvaz@yahoo.com.br

(3) Embrapa Suínos e Aves, Rodovia BR-153, $\mathrm{Km}$ 110, Distrito de Tamanduá, Caixa Postal 321, CEP 89715-899 Concórdia, SC, Brazil. E-mail: everton.krabbe@embrapa.br, valdir.avila@embrapa.br

(4) Universidade Federal de Pelotas, Faculdade de Agronomia Eliseu Maciel, Avenida Eliseu Maciel, s/no, Campus UFPel, Caixa Postal 354, CEP 96160-000 Capão do Leão, RS, Brazil.

E-mail: cristielecontreira@hotmail.com.br

$\bowtie$ Corresponding author

Received

September 24, 2020

Accepted

January 25, 2021

How to cite

SILVA, V.S.; RODRIGUES, K.F.; KRABBE, E.L.; VAZ, R.G.M.V.; ÁVILA, V.S. de; CONTREIRA, C.L. Enzymatic association in the diets of laying hens raised in an alternative cage-free system. Pesquisa Agropecuária Brasileira, v.56, e02275, 2021. DOI: https://doi.org/10.1590/ S1678-3921.pab2021.v56.02275.

\section{Enzymatic association in the diets of laying hens raised in an alternative cage-free system}

\begin{abstract}
The objective of this work was to evaluate the use of enzyme combinations in diets, with different nutritional uplift matrices, for hens raised in an alternative cage-free system. The experiment was carried out with 800 Isa Brown laying hens aged 24-30 weeks, distributed in a 2x2 factorial arrangement, with two combinations of enzymes (phytase and xylanase) and two nutritional matrices (conventional and overvalued uplifts). The treatments were: T1, phytase (450 FTU per kilogram) + xylanase $(12,000$ BXU per kilogram), using matrix I (100 Kcal kg-1 apparent metabolizable energy, $0.16 \%$ calcium, $0.15 \%$ available phosphorus, 0.03 sodium, and $0.02 \%$ digestible lysine); T2, phytase (1,500 FTU per kilogram) and matrix I; T3, phytase (450 FTU per kilogram) + xylanase (12,000 BXU per kilogram), using matrix II (120 Kcal kg-1 apparent metabolizable energy, $0.22 \%$ calcium, $0.20 \%$ available phosphorus, $0.04 \%$ sodium, and $0.05 \%$ digestible lysine); and T4, phytase (1,500 FTU per kilogram) and matrix II. Productive performance variables and external and internal egg quality were analyzed. The use of phytase or of the phytase + xylanase combination, independently of the nutritional matrix used, met the nutrient requirements of the animals and maintained their productive performance. However, the combination phytase + xylanase and the adoption of matrix I was more efficient.
\end{abstract}

Index terms: egg quality, nutritional matrix, phytase, welfare, xylanase.

\section{Associação enzimática na ração de poedeiras criadas em sistema "cage-free" alternativo}

Resumo - O objetivo deste trabalho foi avaliar o uso de associações enzimáticas em rações, com diferentes matrizes nutricionais, para poedeiras criadas em sistema "cage-free" alternativo. O experimento foi realizado com 800 poedeiras Isa Brown de 24-30 semanas de idade, distribuídas em arranjo fatorial $2 \times 2$, com duas associações de enzimas (fitase e xilanase) e duas matrizes nutricionais (convencional e supervalorizada). Os tratamentos foram: T1, fitase (450 FTU por kilogram) + xilanase (12.000 BXU por kilogram), com uso da matriz I (100 Kcal kg-1 de energia metabolizável aparente, $0,16 \%$ de cálcio, $0,15 \%$ de fósforo disponível, $0,03 \%$ de sódio e $0,02 \%$ de lisina digestível); T2, fitase (1.500 FTU por kilogram) e matriz I; T3, fitase (450 FTU por kilogram) + xilanase (12.000 BXU por kilogram), com uso da matriz II $\left(120 \mathrm{Kcal} \mathrm{kg}^{-1}\right.$ de energia metabolizável aparente, $0,22 \%$ de cálcio, $0,20 \%$ de fósforo disponível, 0,04 de sódio e $0,05 \%$ de lisina digestível); e T4, fitase (1.500 FTU por kilogram) e matriz II. Foram analisadas variáveis de desempenho produtivo e qualidade externa e interna dos ovos. O uso de fitase ou da associação fitase + xilanase, independentemente da matriz nutricional utilizada, conseguiu atender às exigências nutricionais dos animais e manter o seu desempenho produtivo. Porém, a combinação fitase + xilanase e a adoção da matriz I foi mais eficiente.

Termos para indexação: qualidade de ovos, matriz nutricional, fitase, bemestar, xilanase. 


\section{Introduction}

Brazilian egg production has been growing fast and reached 49 billion units in 2019, with a consumption per capita of 230 units per year (ABPA, 2020).

However, recently, European Union countries have enacted laws on animal welfare that set strict criteria for poultry farming, such as the ban of laying cages, and the world trend has been to follow this cage-free standard (Weeks et al., 2016).

Among the new strategies for egg production is the free-range system, which allows accessing paddocks with grasses that offer benefits to laying hens, such as: the establishment of social and hierarchical relationships; an increased repertoire of activities, including foraging and investigating; and a greater space and freedom to express behaviors that are considered essential for these animals (Lay Jr et al., 2011).

In the free-range system, birds also need balanced diets that meet their nutritional requirements for maximum productive efficiency (Tutkun et al., 2018). Pasture intake, for example, can have a negative impact on voluntary feed intake, which may lead to undernourishment caused by a reduced absorption of energy, as well as of macro- and micronutrients. This negative effect may be explained by the lack of endogenous enzymes to digest fiber, resulting in a reduced nutrient availability. Therefore, exogenous enzyme supplementation may be a solution to overcome the low nutrient availability due to an uncontrolled fiber intake by free-range layers (Iqbal et al., 2018).

Exogenous enzymes, such as phytase and xylanase, have emerged as an alternative to increase the nutritional value of feedstuffs, as well as to increase digestibility coefficients, especially of nutrients linked to non-starch polysaccharides and antinutritional factors, such as phytate (Ferreira et al., 2015).

Phytase belongs to the group of phosphatases that hydrolyze phytate and release phosphorus and other minerals and proteins (Manangi et al., 2018). Studies have recommended 500 phytase units (FTU) per kilogram as the ideal inclusion level of phytase in poultry diets (Cowieson et al., 2009). However, recently, higher dietary additions of phytase (more than 1,000 FTU per kilogram) have been suggested (Manobhavan et al., 2016). According to Kim et al. (2017), the superdosing of phytase in laying hen diets has a positive effect on egg production rate.
Xylanase is mainly responsible for the hydrolysis of xylan, the main constituent of plant cell wall hemicellulose, increasing digestive motility and reducing energy expenditure in digestion and absorption (Cowieson et al., 2010). According to Souza et al. (2012), xylanase supplementation in laying hen diets resulted in an increase in apparent metabolizable energy (AME) and, consequently, improved the productive performance of the birds.

The results obtained with the use of phytase and xylanase imply in a series of practical techniques for poultry feeding, such as the use of nutritional matrices with uplift of calcium, phosphorus, metabolizable energy, crude protein, and amino acids (Nagata et al., 2011). Research suggests that these enzymes, when combined, have an additive action, which enhances their effects; however, studies on the topic are still limited, especially regarding cage-free production systems (Iqbal et al., 2018).

The objective of this work was to evaluate the use of enzyme combinations in diets, with different nutritional uplift matrices, for hens raised in an alternative cage-free system.

\section{Materials and Methods}

The research was conducted in an egg farm located in the rural area of the municipality of Ouro, in the state of Santa Catarina, Brazil (27¹9'49'S, 51 $35^{\circ} 53^{\prime \prime} \mathrm{W}$ ), in partnership with Embrapa Suínos e Aves. The experiment was carried out from December 18, 2017, to January 29, 2018, comprising a six-week production cycle. The study was approved by the ethics committee on animal use of Embrapa Suínos e Aves, protocol number 015/2018.

Eight hundred Isa Brown laying hens, aged 24-30 weeks, were housed in a wooden shed, divided into 20 floor pens with $5.6 \mathrm{~m}^{2}$ area and $10 \mathrm{~cm}$-thick pine wood shavings covering the floor. Each pen had a perch and a wooden nest with eight nesting boxes, containing wood shavings at the bottom; pendulum feeders and nipple drinkers were installed. A small door allowed accessing an external paddock of $5.6 \mathrm{~m}^{2}$, covered with a $10 \mathrm{~cm}$ layer of sand for laying. This production system is a mid-term laying rearing system, mixing cage-free practices with free-range production criteria.

At the beginning and at the end of the six-week cycle, birds were weighed individually, for each 
experimental unit. The eggs laid on the last day of the six-week period in each pen were weighed individually, and arithmetic means were calculated. Based on their weight, 20 eggs were selected, with a margin of $\pm 5 \%$ mean weight. After selection, the eggs were identified and evaluated. For analytical purposes, 10 eggs were used for the internal quality analysis and 10 eggs for shell strength determination.

Four treatments were carried out in a complete randomized block design, in a $2 \times 2$ factorial arrangement, with two combinations of enzymes (phytase and xylanase) and two nutritional matrices (conventional and overvalued uplifts, with five replicates and 40 birds per experimental unit). The blocks were established according to bird weight at 19 weeks of age. The treatments were: T1, phytase [450 phytase activity unit (FTU) per kilogram] + xylanase [12,000 birch xylan units (BXU) per kilogram], using nutritional uplift matrix I (100 Kcal kg-1 AME, 0.16\% calcium, $0.15 \%$ available phosphorus, $0.03 \%$ sodium, and $0.02 \%$ digestible lysine); $\mathrm{T} 2$, phytase $(1,500$ FTU per kilogram), also using matrix I; T3, phytase (450 FTU per kilogram) + xylanase $(12,000$ BXU per kilogram), using nutritional adjustment matrix II (120 Kcal kg-1 AME, $0.22 \%$ calcium, 0.20 available phosphorous, $0.04 \%$ sodium, and $0.05 \%$ digestible lysine); and T4, phytase (1,500 FTU per kilogram), also using matrix II.

Considering the experiment was set to support practical validation, there was no negative control treatment, as the use of phytase is a common and consolidated concept in the egg production system. Therefore, the enzyme doses and nutritional matrices were explored based on this premise.

Nutritional uplifts were considered for the diet formulations, which, in practice, implied in thereduction of the nutritional contents in the diet, formulated to meet the normal nutritional requirements for the laying hen phase, according to the management guide for the Isa Brown line (ISA, 2007); the energetic and nutritional values of each ingredient were determined following Rostagno (2017). The experimental diets were based on corn, soybean meal, wheat bran, minerals, vitamins, and amino acids (Table 1).

Laying hen performance was measured using: egg production ratio (\%), average egg weight, egg mass, feed conversion ratio, and bird livability (\%). For internal quality evaluation, before broken, the eggs were individually weighed. To assess specific gravity, all eggs were placed in buckets with saline solutions, from the lowest to the highest concentration of sodium chloride, ranging from 1.066 to 1.102, with an interval of 0.004 (Zumbado, 1983).

Soon afterwards, the eggs were carefully opened and placed individually in Petri dishes where thick albumen height was measured using a digital caliper. This measure, together with egg weight, was used to calculate the Haugh unit (HU) by the formula described by Card \& Nesheim (1966): $\mathrm{HU}=100 \log \left(\mathrm{h}+7.57-1.7 \mathrm{w}^{0.37}\right)$, where $\mathrm{h}$ is thick albumen height ( $\mathrm{mm}$ ) and $\mathrm{w}$ is egg weight $(\mathrm{g})$.

Yolk color was assessed using the CR-400 chroma meter (Konica Minolta Inc., Tokyo, Japan). The parameters measured were those of the Commission International de I'Eclairage (CIEL) system (McLaren, 1976): L*, lightness; $a^{*}$, red/green coordinate; and $b^{*}$, yellow/blue coordinate. Using parameters $a^{*}$ and $b^{*}$, parameter $C^{*}$ (chroma) was obtained, indicating color saturation measures, by the formula: $\mathrm{C}^{*}=\left[\left(\mathrm{a}^{*}\right)^{2}+\left(\mathrm{b}^{*}\right)^{2}\right]^{1 / 2}$.

After the color analysis, yolk and albumen were separated. The yolk was weighed individually on a digital scale to calculate the yolk percentage of each egg, using the formula: $\% \mathrm{G}=$ (yolk weight/egg weight) $\times 100$.

After weighed, the yolks were placed in another Petri dish, where their diameter $(\mathrm{mm})$ and height $(\mathrm{mm})$ were measured with a digital caliper, in order to obtain the yolk index value through the relationship between these two measures. Albumen weight (g) was obtained by calculating the difference between total egg weight and shell and yolk weights. Using weight, it was possible to calculate the albumen percentage of each egg.

Shell breaking strength was determined in the equatorial region of the egg with the aid of the TA.X T2 texture analyzer (Stable Micro Systems, Surrey, United Kingdom), using a $2 \mathrm{~mm}$ rupture probe, which recorded the force (kgf) necessary to break the shell.

The shells were washed with water and dried at room temperature for 72 hours. After drying, they were individually weighed on a digital scale and then fragments of the shell were removed from three egg regions (basal, apical, and medial). The thickness of each fragment was measured using the 293-23030 digital micrometer, with a $0.001 \mathrm{~mm}$ resolution 
(Mitutoyo Company, Kawasaki, Japan). To obtain the final value of shell thickness, an arithmetic mean was calculated using the values of the three egg regions (Barbosa et al., 2012).

The data of the evaluated variables were tested for normality and homoscedasticity by Shapiro-Wilk's and Levene's tests, respectively. With these assumptions met, the variables were then subjected to the analysis of variance, using the Statistix statistical software (Analytical Software, Tallahassee, FL, USA) in a $2 \times 2$ factorial arrangement. The means of the responses were compared by the F-test, at 5\% probability, and the means of each treatment were compared by Tukey's test, also at $5 \%$ probability.

Table 1. Composition of the experimental diets fed to laying hens raised in a free-range system.

\begin{tabular}{|c|c|c|c|c|}
\hline \multirow{2}{*}{$\begin{array}{l}\text { Ingredients } \\
(\%)\end{array}$} & \multicolumn{2}{|c|}{ Matrix I ${ }^{(1)}$} & \multicolumn{2}{|c|}{ Matrix II ${ }^{(2)}$} \\
\hline & Phy $+\mathrm{Xyl}^{(3)}$ & Phytase (1,500 FTU per kg) & Phy + Xyl & Phytase (1,500 FTU per kg) \\
\hline Corn & 59.04 & 59.04 & 60.00 & 60.00 \\
\hline Soybean meal $46 \%$ & 21.57 & 21.57 & 21.43 & 21.43 \\
\hline Wheat bran & 7.500 & 7.500 & 7.500 & 7.500 \\
\hline Limestone & 9.290 & 9.290 & 9.300 & 9.300 \\
\hline Dicalcium phosphate & 0.248 & 0.248 & 0.000 & 0.000 \\
\hline Soybean oil & 1.590 & 1.590 & 1.070 & 1.070 \\
\hline Common salt & 0.266 & 0.266 & 0.240 & 0.240 \\
\hline DL-methionine & 0.156 & 0.156 & 0.156 & 0.156 \\
\hline L-lysine HCL & 0.060 & 0.060 & 0.025 & 0.025 \\
\hline Vitamin and mineral supplement ${ }^{(4)}$ & 0.170 & 0.170 & 0.170 & 0.170 \\
\hline Mycotoxin sequestrant ${ }^{(5)}$ & 0.100 & 0.100 & 0.100 & 0.100 \\
\hline Phytase & 0.0045 & 0.015 & 0.0045 & 0.015 \\
\hline Xylanase & 0.0075 & 0.000 & 0.0075 & 0.000 \\
\hline Total & 100.00 & 100.00 & 100.00 & 100.00 \\
\hline \multicolumn{5}{|l|}{ Nutritional composition } \\
\hline Metabolizable energy $\left(\mathrm{Kcal} \mathrm{kg}^{-1}\right)$ & 2750 & 2750 & 2730 & 2730 \\
\hline Crude protein $(\%)$ & 15.00 & 15.00 & 15.00 & 15.00 \\
\hline Crude fiber $(\%)$ & 2.88 & 2.88 & 2.89 & 2.89 \\
\hline Calcium (\%) & 3.64 & 3.64 & 3.58 & 3.58 \\
\hline Available phosphorus (\%) & 0.16 & 0.16 & 0.11 & 0.11 \\
\hline Total phosphorus (\%) & 0.41 & 0.41 & 0.36 & 0.36 \\
\hline Sodium $(\%)$ & 0.12 & 0.12 & 0.11 & 0.11 \\
\hline Linoleic acid (\%) & 2.31 & 2.31 & 2.06 & 2.06 \\
\hline Fat $(\%)$ & 4.35 & 4.35 & 3.88 & 3.88 \\
\hline Digestible methionine (\%) & 0.36 & 0.36 & 0.36 & 0.36 \\
\hline Digestible methionine + cystine $(\%)$ & 0.60 & 0.60 & 0.60 & 0.60 \\
\hline Digestible lysine (\%) & 0.71 & 0.71 & 0.68 & 0.68 \\
\hline Digestible threonine (\%) & 0.48 & 0.48 & 0.48 & 0.48 \\
\hline Digestible tryptophan (\%) & 0.16 & 0.16 & 0.16 & 0.16 \\
\hline
\end{tabular}

${ }^{(1)}$ Matrix I, $100 \mathrm{Kcal} \mathrm{kg}^{-1}$ apparent metabolizable energy, $0.16 \%$ calcium, $0.15 \%$ available phosphorus, $0.03 \%$ sodium, and $0.02 \%$ digestible lysine. (2) Matrix II, $120 \mathrm{Kcal} \mathrm{kg}^{-1}$ apparent metabolizable energy, $0.22 \%$ calcium, $0.20 \%$ available phosphorous, $0.04 \%$ sodium, and $0.05 \%$ digestible lysine. (3) Phy + Xyl, phytase (450 FTU per kilogram) + xylanase (12,000 BXU per kilogram). ${ }^{(4)}$ Product composition (guarantee levels per kilogram of product): 3,330 mg copper, 16,653 mg iron, 33,343 mg manganese, $101 \mathrm{mg}$ selenium, 33,333 mg zinc, 4,000.800 IU vitamin A, 1,000.200 IU vitamin D3, 16,670 IU vitamin E, 1,674 mg vitamin K3, $980 \mathrm{mg}$ vitamin B1, 10,000 mcg vitamin B2, 1,030 mg folic acid, 4,983 mg pantothenic acid, 16,670 mg niacin, $100 \mathrm{mg}$ biotin, 140,592 mg choline, and $666.50 \mathrm{mg}$ iodine. ${ }^{(5)}$ Aluminosilicate toxin binder. 


\section{Results and Discussion}

There was no interaction $(\mathrm{p}>0.05)$ between enzymes and nutritional matrixes for any of the analyzed variables of productive performance (Table 2).

All productive performance variables for the specific phase evaluated are within the range suggested by the Isa Brown - Management Guide (ISA, 2007). This means that phytase (1,500 FTU per kilogram) alone or the combination phytase (450 FTU per kilogram) + xylanase (12,000 BXU per kilogram), independently of the used nutritional uplift, guaranteed the productive performance of the birds according to their potential.

When assessing the isolated effect of the enzyme strategy, the combination phytase + xylanase resulted in a higher egg mass value and in a better feed conversion ratio per dozen eggs (Table 2).

The obtained results are in line with those reported by Rezende et al. (2013), who also found that the enzyme improved the feed conversion ratio per dozen eggs. According to the authors, phytase makes complexed phosphorus available to phytic acid, improving its utilization, as well as other nutrients (calcium, iron, manganese, zinc, protein, and metabolizable energy) previously unavailable due to the complexation of the enzyme with phytate.

Taylor et al. (2018) observed a positive interaction between phytase and xylanase for the feed conversion ratio. The improvement in this ratio is attributed to the increase in nutrient availability in the substrate degraded by phytase. In addition, the presence of xylanase increases the permeability of the cell wall aleurone present in the diets, improving phytase action on phytate degradation.

Matrix I promoted higher values of egg weight and egg mass in relation to matrix II, set for greater dietary nutritional reductions (Table 2).

Costa et al. (2009) concluded that the energy requirement of laying hens is conditioned to factors such as body weight, weight gain, and egg mass production. Therefore, significant reductions in the energy level of the diets can affect these variables, as observed for egg mass in the present study.

Diets formulated with available phosphorus and calcium levels far below bird requirements can impair the feed conversion ratio and reduce nutrient metabolizability coefficients, resulting in a lower egg mass and weight (Tejedor et al., 2001). Moreover, dietary available phosphorus deficiency results in a severe reduction in phosphorus intake, and very low levels of this mineral can impair bird performance (Parmer et al., 1987).

Regarding the external quality of the eggs, there was an interaction between the inclusion of enzymes and nutritional matrices for shell percentage (Table 3). As a result of breaking down the interaction for shell percentage (Table 4), matrix II supplemented with phytase (1,500 FTU per kilogram) alone presented the highest value $(10.20 \%)$ for this parameter.

Table 2. Productive performance of laying hens fed different enzyme combinations in the period of 24 to 30 weeks of age in a free-range system.

\begin{tabular}{|c|c|c|c|c|c|}
\hline Treatment & $\begin{array}{c}\text { Egg production } \\
(\%)\end{array}$ & $\begin{array}{l}\text { Average egg weight } \\
\text { (g) }\end{array}$ & $\begin{array}{c}\text { Egg mass } \\
\text { (g per bird per day) }\end{array}$ & $\begin{array}{c}\text { FCR } \\
\text { (kg per dozen) }\end{array}$ & $\begin{array}{c}\text { Livability } \\
(\%)\end{array}$ \\
\hline \multicolumn{6}{|l|}{ Enzyme } \\
\hline Phytase + xylanase $^{(1)}$ & 95.84 & 59.18 & 57.24 & 1.42 & 100.0 \\
\hline Phytase (1,500 FTU per kg) & 94.66 & 58.60 & 55.15 & 1.45 & 99.51 \\
\hline \multicolumn{6}{|l|}{ Nutritional matrix } \\
\hline Matrix I $I^{(2)}$ & 95.04 & 59.54 & 57.10 & 1.43 & 99.51 \\
\hline Matrix II ${ }^{(3)}$ & 95.46 & 58.23 & 55.29 & 1.44 & 100.0 \\
\hline \multicolumn{6}{|l|}{ Probability } \\
\hline Enzyme & 0.1468 & 0.3167 & $0.0034 *$ & $0.0040 *$ & 0.1286 \\
\hline Nutritional matrix & 0.5894 & $0.0396^{*}$ & $0.0101 *$ & 0.8618 & 0.1286 \\
\hline Enzyme $\mathrm{x}$ nutritional matrix & 0.5129 & 0.5421 & 0.4461 & 0.8468 & 0.1286 \\
\hline Coefficient of variation (\%) & 1.64 & 1.91 & 1.73 & 1.33 & 0.67 \\
\hline
\end{tabular}


Studies have shown that, as the level of phosphorus in the diet increases, there is a reduction in shell quality indices. Borrmann et al. (2001), for example, observed the influence of phosphorus and phytase on eggshell percentage. The obtained results suggest that the effect of phytic phosphorus hydrolysis by phytase

Table 3. External quality of the eggs of laying hens fed different enzyme combinations in the period of 24 to 30 weeks of age in a free-range system.

\begin{tabular}{|c|c|c|c|c|}
\hline Treatment & $\begin{array}{l}\text { Specific } \\
\text { gravity }\end{array}$ & $\begin{array}{c}\mathrm{ST} \\
(\mu \mathrm{m})\end{array}$ & $\begin{array}{c}\text { Shell } \\
\text { percentage }\end{array}$ & $\begin{array}{c}\text { BS } \\
(\mathrm{kgf})\end{array}$ \\
\hline \multicolumn{5}{|l|}{ Enzyme } \\
\hline Phytase + xylanase $^{(1)}$ & $1,088.8$ & 0.4263 & 9.88 & 3.36 \\
\hline Phytase (1,500 FTU per kg) & $1,088.9$ & 0.4319 & 9.96 & 3.33 \\
\hline \multicolumn{5}{|l|}{ Nutritional matrix } \\
\hline Matrix $I^{(2)}$ & $1,088.8$ & 0.4291 & 9.91 & 3.35 \\
\hline Matrix II ${ }^{(3)}$ & $1,088.8$ & 0.4290 & 9.93 & 3.34 \\
\hline \multicolumn{5}{|l|}{ Probability } \\
\hline Enzyme & 0.8902 & 0.0867 & 0.5895 & 0.6264 \\
\hline Nutritional matrix & 0.9280 & 0.5089 & 0.8740 & 0.8937 \\
\hline Enzyme $\mathrm{x}$ nutritional matrix & 0.0528 & 0.1270 & $0.0065^{*}$ & 0.3168 \\
\hline $\mathrm{CV}(\%)$ & 0.41 & 5.47 & 5.42 & 13.12 \\
\hline \multicolumn{5}{|c|}{ 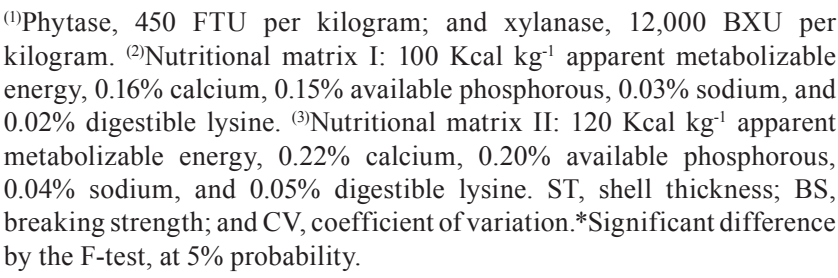 } \\
\hline
\end{tabular}

is more significant when the diet contains a lower level of calcium.

There was no interaction between enzymes and nutritional matrix for any of the egg internal quality parameters (Table 5). However, yolk percentage was affected by the enzymes, showing the highest value with the combination phytase + xylanase. Together, these two enzymes increased yolk percentage and, consequently, egg mass (Table 2). An increase in egg mass due to the increase in the amount of albumen and yolk has been reported as one of the main effects of supplementing the diets of laying hens with enzymes (Soto-Salanova \& Wyatt, 1997). In contrast, Oba et al. (2013) found no difference in the percentage of yolk

Table 4. Interaction breakdown for shell percentage of the eggs of laying hens fed different enzyme combinations in the period of 24 to 30 weeks of age in a free-range system ${ }^{(1)}$.

\begin{tabular}{lcc}
\hline $\begin{array}{l}\text { Nutritional } \\
\text { matrix }\end{array}$ & ${\text { Phytase }+ \text { xylanase }^{(2)}}^{2} \begin{array}{c}\text { Phytase } \\
(1,500 \text { FTU per kg })\end{array}$ \\
\hline & \multicolumn{2}{c}{ Shell percentage } \\
Matrix I ${ }^{(3)}$ & 10.09 & $9.74 \mathrm{~B}$ \\
Matrix II $^{(4)}$ & $9.67 \mathrm{~b}$ & $10.20 \mathrm{Aa}$ \\
\hline
\end{tabular}

${ }^{(1)}$ Different letters, uppercase in the same column and lowercase in the same row, indicate significant differences by Tukey's test, at $5 \%$ probability. ${ }^{(2)}$ Phytase, 450 FTU per kilogram; and xylanase, 1,2000 BXU per kilogram. ${ }^{(3)}$ Nutritional matrix I: $100 \mathrm{Kcal} \mathrm{kg}^{-1}$ apparent metabolizable energy, $0.16 \%$ calcium, $0.15 \%$ available phosphorous, $0.03 \%$ sodium, and $0.02 \%$ digestible lysine. ${ }^{(4)}$ Nutritional matrix II: $120 \mathrm{Kcal} \mathrm{kg}{ }^{-1}$ apparent metabolizable energy, $0.22 \%$ calcium, $0.20 \%$ available phosphorous, $0.04 \%$ sodium, and $0.05 \%$ digestible lysine.

Table 5. Internal quality of the eggs of laying hens fed different enzyme combinations in the period of 24 to 30 weeks of age in a free-range system.

\begin{tabular}{|c|c|c|c|c|c|c|c|c|}
\hline Treatment & $\begin{array}{l}\text { Yolk } \\
(\%)\end{array}$ & $\begin{array}{c}\text { Yolk } \\
\text { index }\end{array}$ & $\begin{array}{c}\text { Albumen } \\
(\%)\end{array}$ & $\begin{array}{c}\text { Haugh } \\
\text { unit }\end{array}$ & $\mathrm{L}^{*}$ & $a^{*}$ & $\mathrm{~b}^{*}$ & Chroma \\
\hline \multicolumn{9}{|l|}{ Enzyme } \\
\hline Phytase + xylanase ${ }^{(1)}$ & 24.72 & 0.3723 & 65.65 & 91.47 & 59.13 & -6.40 & 41.85 & 42.39 \\
\hline Phytase 1,500 FTU per kg & 24.06 & 0.3809 & 65.65 & 91.06 & 58.92 & -6.43 & 40.94 & 41.46 \\
\hline \multicolumn{9}{|l|}{ Nutritional matrix } \\
\hline Matrix I(2) & 24.30 & 0.3819 & 65.64 & 91.02 & 58.99 & -6.32 & 41.92 & 42.42 \\
\hline Matrix II ${ }^{(3)}$ & 24.47 & 0.3713 & 65.66 & 91.50 & 59.05 & -6.50 & 40.86 & 41.43 \\
\hline \multicolumn{9}{|l|}{ Probability } \\
\hline Enzyme & $0.0039 *$ & 0.1192 & 0.6111 & 0.6040 & 0.5292 & 0.7514 & $0.0418^{*}$ & $0.0347 *$ \\
\hline Nutritional matrix & 0.4807 & 0.0546 & 0.5622 & 0.5436 & 0.8519 & 0.0745 & $0.0191^{*}$ & $0.0265 *$ \\
\hline Enzyme x nutritional matrix & 0.7414 & 0.0804 & 0.0738 & 0.8502 & 0.1341 & 0.4366 & 0.7403 & 0.8726 \\
\hline $\mathrm{CV}(\%)$ & 6.34 & 9.91 & 3.94 & 5.87 & 3.98 & 10.88 & 7.58 & 7.32 \\
\hline
\end{tabular}


when feeding layers with diets containing different levels of an enzyme complex (carbohydrases, phytase, and protease).

There was an effect of enzymes and nutritional matrix on color parameter $b^{*}$, which indicates the color in the range from yellow $\left(+b^{*}\right)$ to blue $\left(-b^{*}\right)$, and on chroma, the ratio of $a^{*}$ to $b^{*}$ (Table 5). The combination phytase + xylanase and matrix I affected yolk color intensity. Similar results were obtained by Brunelli et al. (2012), who found that birds fed diets containing phytase (1,000 FTU per kilogram) laid eggs with more orange yolks than those fed diets without the enzyme. Pirgozliev et al. (2010) observed that the supplementation of xylanase $(12,000$ and $16,000 \mathrm{BXU}$ per kilogram) in the diet intensified the color of the egg yolk.

The improvement in egg yolk pigmentation by adding xylanase can be explained by the greater digestibility of hemicellulose, a component of the plant cell wall, resulting in a greater release and use of pigments (Çiftci et al., 2003). One of the effects of supplementing the diets of laying hens with phytase is the increase in pigment absorption, since phytic acid has a depigmenting and antioxidant activity (SotoSalanova \& Wyatt, 1997).

\section{Conclusion}

The combination phytase (450 FTU per kilogram) + xylanase (12,000 BXU per kilogram), with the adoption of matrix I $\left(100 \mathrm{Kcal} \mathrm{kg}^{-1}\right.$ apparent metabolizable energy, $0.16 \%$ calcium, $0.15 \%$ available phosphorus, $0.03 \%$ sodium, and $0.02 \%$ digestible lysine), is more efficient to maintain the egg quality of laying hens raised in a free-range system.

\section{Acknowledgments}

To Conselho Nacional de Desenvolvimento Científico e Tecnológico (CNPq), for financial support; and to Programa de Pós-Graduação em Ciência Animal Tropical of Universidade Federal do Tocantins (UFT) and to Embrapa Suínos e Aves, for the opportunity to carry out the experiment.

\section{References}

ABPA. Associação Brasileira de Proteína Animal. Relatório anual 2020. Available at: <http://abpa-br.org/wp-content/ uploads/2020/05/abpa_relatorio_anual_2020_portugues_web. pdf $>$. Accessed on: Aug. 82020.

BARBOSA, V.M.; BAIÃO, N.C.; MENDES, P.M.M.; ROCHA, J.S.R; POMPEU, M.A.; LARA, L.J.C.; MARTINS, N.R.S.; NELSON, D.L.; MIRANDA, D.J.A.; CUNHA, C.E.; CARDOSO, D.M.; CARDEAL, P.C. Avaliação da qualidade da casca dos ovos provenientes de matrizes pesadas com diferentes idades. Arquivo Brasileiro de Medicina Veterinária e Zootecnia, v.64, p.1036-1044, 2012. DOI: https://doi.org/10.1590/S010209352012000400033.

BORRMANN, M.S.L.; BERTECHINI, A.G.; FIALHO, E.T.; OLIVEIRA, B.L. Efeitos da adição de fitase com diferentes níveis de fósforo disponível em rações de poedeiras de segundo ciclo. Revista Ciências Agrotécnicas, v.25, p.181-187, 2001.

BRUNELLI, S.R.; PINHEIRO, J.W.; FONSECA, N.A.N.; SILVA, C.A. da. Efeito de diferentes níveis de farelo de gérmen de milho desengordurado em dietas suplementadas com fitase para poedeiras comerciais. Semina: Ciências Agrárias, v.33, p.1991-2000, 2012. DOI: https://doi.org/10.5433/1679-0359.2012v33n5p1991.

CARD, L.E.; NESHEIM, M.C. Poultry production. Philadelphia: Lea \& Febiger, 1966. 399p.

ÇIFTCI, İ.; YENICE, E.; GÖKÇEYREK, D.; ÖZTÜRK, E. Effects of energy level and enzyme supplementation in wheatbased layer diets on hen performance and egg quality. Acta Agriculturae Scandinavica, Section A - Animal Science, v.53, p.113-119, 2003. DOI: https://doi.org/10.1080/09064700310017967.

COSTA, F.G.P.; QUIRINO, B.J.S.; GIVISIEZ, P.E.N.; SILVA, J.H.V.; ALMEIDA, H.H.S.; COSTA, J.S.; GOULART, C.C. Poedeiras alimentadas com diferentes níveis de energia e óleo de soja na ração. Archivos de Zootecnia, v.58, p.405-411, 2009. DOI: https://doi.org/10.21071/az.v58i223.5181.

COWIESON, A.J.; BEDFORD, M.R.; RAVINDRAN, V. Interactions between xylanase and glucanase in maize-soy-based diets for broilers. British Poultry Science, v.51, p.246-257, 2010. DOI: https://doi.org/10.1080/00071661003789347.

COWIESON, A.J.; BEDFORD, M.R.; SELLE, P.H.; RAVINDRAN, V. Phytate and microbial phytase: implications for endogenous nitrogen losses and nutrient availability. World's Poultry Science Journal, v.65, p.401-418, 2009. DOI: https://doi.org/10.1017/S0043933909000294.

FERREIRA, C.B.; GERALDO, A.; VIEIRA FILHO, J.A.; BRITO, J.A.G.; BERTECHINI, A.G.; PINHEIRO, S.R.F. Associação de carboidrases e fitase em dietas valorizadas e seus efeitos sobre desempenho e qualidade dos ovos de poedeiras leves. Arquivo Brasileiro de Medicina Veterinária e Zootecnia, v.67, p.249254, 2015. DOI: https://doi.org/10.1590/1678-7051.

IQBAL, Z.; ROBERTS, J.; PEREZ-MALDONADO, R.A.; GOODARZI BOROOJENI, F.; SWICK, R.A.; RUHNKE, I. Pasture, multi-enzymes, benzoic acid and essential oils positively influence performance, intestinal organ weight and egg quality in free-range laying hens. British Poultry Science, v.59, p.180-189, 2018. DOI: https://doi.org/10.1080/00071668.2017.1403566.

ISA. Institut de Sélection Animale. ISA Brown Management Guide. 2007. Available at: <http://www.isapoultry.com>. Accessed on: Sept. 172020. 
KIM, J.H.; PITARGUE, F.M.; JUNG, H.; HAN, G.P.; CHOI, H.S.; KIL, D.Y. Effect of superdosing phytase on productive performance and egg quality in laying hens. Asian-Australasian Journal of Animal Sciences, v.30, p.994-998, 2017. DOI: https://doi.org/10.5713/ajas.17.0149.

LAY JR, D.C.; FULTON, R.M.; HESTER, P.Y.; KARCHER, D.M.; KJAER, J.B.; MENCH, J.A.; MULLENS, B.A.; NEWBERRY, R.C.; NICOL, C.J.; O'SULLIVAN, N.P.; PORTER, R.E. Hen welfare in different housing systems. Poultry Science, v.90, p.278-294, 2011. DOI: https://doi.org/10.3382/ps.2010-00962.

MANANGI, M.K.; MAHARJAN, P.; COON, C.N. Effect of different concentrations of dietary $\mathrm{P}$ and $\mathrm{Ca}$ on plasma inorganic $\mathrm{P}$ and urinary $\mathrm{P}$ excretion using noncolostomized and colostomized broilers. Poultry Science, v.97, p.522-530, 2018. DOI: https://doi.org/10.3382/ps/pex305.

MANOBHAVAN, M.; ELANGOVAN, A.V.; SRIDHAR, M.; SHET, M.; AJITH, S.; PAL, D.T.; GOWDA, N.K.S. Effect of super dosing of phytase on growth performance, ileal digestibility and bone characteristics in broilers fed corn-soya-based diets. Journal of Animal Physiology and Animal Nutrition, v.100, p.93-100, 2016. DOI: https://doi.org/10.1111/jpn.12341.

MCLAREN, K. XIII - The development of the CIE 1976 (L* $a^{*} b^{*}$ ) uniform colour space and colour-difference formula. Coloration Technology, v.92, p.338-341, 1976. DOI: https://doi.org/10.1111/j.1478-4408.1976.tb03301.x.

NAGATA, A.K.; RODRIGUES, P.B.; ALVARENGA, R.R.; ZANGERONIMO, M.G.; DONATO, D.C.Z.; SILVA, J.H.V. da. Carcass characteristics of broilers at 42 days receiving diets with phytase in different energy and crude protein levels. Ciência e Agrotecnologia, v.35, p.575-581, 2011. DOI: https://doi.org/10.1590/S1413-70542011000300020.

OBA, A.; PINHEIRO, J.W.; SILVA, C.A. da; CASTRO-GOMEZ, R.J.H.; BENITEZ, C.R.; UENO, F.Y.; BORGES, C.A.; ALMEIDA, M. de. Características produtivas, qualitativas e microbiológicas de galinhas poedeiras alimentadas com diferentes níveis de complexo enzimático. Semina: Ciências Agrárias, v.34, p.4179-4186, 2013. Supl. 2. DOI: https://doi.org/10.5433/16790359.2013v34n6Supl2p4179.

PARMER, T.G.; CAREW, L.B.; ALSTER, F.A.; SCANES, C.G. Thyroid function, growth hormone, and organ growth in broilers deficient in phosphorus. Poultry Science, v.66, p.1995-2004, 1987. DOI: https://doi.org/10.3382/ps.0661995.

PIRGOZLIEV, V.; BEDFORD, M.R.; ACAMOVIC, T. Effect of dietary xylanase on energy, amino acid and mineral metabolism, and egg production and quality in laying hens. British Poultry
Science, v.51, p.639-647, 2010. DOI: https://doi.org/10.1080/0007 1668.2010.514325.

REZENDE, J.C.R.; LAURENTIZ, A.C. de; FILARDI, R. da S.; FASCINA, V.B.; BERTO, D.A.; SOBRANE FILHO, S.T. Níveis de fósforo e fitase para poedeiras comerciais leves. Boletim de Indústria Animal, v.70, p.149-157, 2013. DOI: https://doi.org/10.17523/bia.v70n2p149.

ROSTAGNO, H.S. (Ed.). Tabelas brasileiras para aves e suínos: composição de alimentos e exigências nutricionais. 4.ed. Viçosa: Ed. da UFV, 2017. 488p.

SOTO-SALANOVA, M.F.; WYATT, C.L. Uso de enzimas para alcanzar el maximo potencial de las materias primas para dietas de avicultura. Minneapolis: Midwest Poultry Federation Convention, 1997.

SOUZA, K.M.R. de; FARIA, D.E. de; NAKAGI, V. de S.; CARÃO, Á.C. de P.; PACHECO, B.H.C.; TREVISAN, R.B.; GOMES, G.A. Metabolizable energy values of diets supplemented with xylanase determined with laying hens. Revista Brasileira de Zootecnia, v.41, p.2433-2440, 2012. DOI: https://doi.org/10.1590/S151635982012001200008.

TAYLOR, A.E.; BEDFORD, M.R.; PACE, S.C.; MILLER, H.M. The effects of phytase and xylanase supplementation on performance and egg quality in laying hens. British Poultry Science, v.59, p.554-561, 2018. DOI: https://doi.org/10.1080/0007 1668.2018.1483575.

TEJEDOR, A.A.; ALBINO, L.F.T.; ROSTAGNO, H.S.; VIEITES, F.M. Efeito da adição da enzima fitase sobre o desempenho e a digestibilidade ileal de nutrientes. Revista Brasileira de Zootecnia, v.30, p.802-808, 2001. DOI: https://doi.org/10.1590/ S1516-35982001000300027.

TUTKUN, M.; DENLI, M.; DEMIREL, R. Productivity and egg quality of two commercial layer hybrids kept in free-range system. Turkish Journal of Agriculture - Food Science and Technology, v.6, p.1444-1447, 2018. DOI: https://doi.org/10.24925/ turjaf.v6i10.1444-1447.2070.

WEEKS, C.A.; LAMBTON, S.L.; WILLIAMS, A.G. Implications for welfare, productivity and sustainability of the variation in reported levels of mortality for laying hen flocks kept in different housing systems: a meta-analysis of ten studies. PLoS ONE, v.11, e0146394, 2016. DOI: https://doi.org/10.1371/journal. pone. 0146394 .

ZUMBADO, M. La gravedad especifica para determinar la calidad del cascarón. Avicultura Profesional, v.1, p.8-10, 1983. 